\title{
Pelatihan Penggunaan Alat Laboratorium Fisika Di SMP Pusaka Rawaselang
}

\author{
Training of The use Of Physics Laboratory Tools In SMP Pusaka Rawaselang
}

\section{Taat Guswantoro*, Manogari Sianturi, Faradiba, Samuel Gideon, Septina Severina Lumbantobing, Nya Daniaty Malau, Yohana Lumbantobing, Sumiati, Seprianus}

\author{
Program Studi Pendidikan Fisika, FKIP, Universitas Kristen Indonesia, Jl. Mayjen Sutoyo \\ No.2, Jakarta Timur.*Email : taat.guswantoro@uki.ac.id
}

\begin{abstract}
Abstrak
Laboratorium merupakan sebuah sarana yang mendukung pembelajaran khususnya IPA, namun beberapa sekolah yang berada di daerah belum memiliki peralatan laboratorium yang memadahi, salah satunya adalah SMP Pusaka yang berada kecamatan Ciranjang. Pengukuran adalah salah satu materi dari pelajaran IPA, dalam melakukan pengukuran diperlukan alat ukur. Alat ukur yang sering diujikan di ujian nasional adalah jangka sorong, micrometer skrup dan multitester, tetapi alat ukur ini tidak tersedia di SMP Pusaka. Program Studi Pendidikan Fisika Universitas Kristen Indonesia melakukan pengabdian kepada masyarakat ke SMP Pusaka dengan melakukan kegiatan pelatihan penggunaan alat laboratorium berupa alat ukur jangka sorong, mikrometer skrup dan multitester serta menyumbangkan alat-alat tersebut. Pelatihan dilaksanakan kepada siswa kelas 7 SMP sejumlah 29 siswa, setelah pemaparan tim melakukan pendampingan kepada siswa untuk melakukan pengukuran dan mengisi lembar kerja yang telah disediakan, kemudian diberikan kuesioner untuk mengetahui pemahaman siswa dan kesan kepada instruktur. Dari hasil kuesioner yang dijawab oleh siswa menyatakan bahwa materi pelatihan mudah dipahami, diaplikasikan dan menambah pengetahuan, secara keseluruhan materi yang diajarkan mendapatkan respon baik dengan presentase rata-rata 86,6\%. Menurut kesan para siswa pelatih dari Pendidikan Fisika UKI memberikan perhatian, pendampingan dan penyajian materi yang baik dengan persentase rata-rata $85,4 \%$.
\end{abstract}

Kata kunci: Pengabdian kepada masyarakat, pelatihan, alat ukur, laboratorium

\begin{abstract}
The laboratory is a means that supports learning, especially science, but some schools in the suburbs do not have adequate laboratory equipment, one of them is SMP Pusaka located in Ciranjang sub-district. Measurement is one of the material from the science lesson, when we do the measurement will need measuring tools. Measuring tools that often tested in national examinations are calipers, micrometer screw and multitester, but this measuring tools is not available in SMP Pusaka. Physics Education Study Program of Universitas Kristen Indonesia have done a social services to SMP Pusaka by training to use the laboratory tools in the form of calipers, micrometer skrew and multitester and donating these tools. The training was carried out for grade 7 of SMP Pusaka totaling 29 students, after presentation, the team assisting the students to take measurements and fill in the worksheets that had been provided, then given a questionnaire to know students' understanding and impressions to the instructor. From the results of the questionnaire answered by the students show that the training material was easy to understand, applicable and increasing their knowledge, the overall material taught received a good response with an average percentage of $86.4 \%$. According to the impression the students, trainer from Physics Education Program of UKI gave attention, assistance and good presentation of material with an average percentage of $85.7 \%$.
\end{abstract}

Key words: Social services, training, measuring tools, laboratories.

PENDAHULUAN
Mata pelajaran fisika bagi sebagian besar anak usia sekolah adalah pelajaran yang dianggap sulit, baik konsep maupun 
persamaannya. Banyaknya konsep dan rumus yang harus diketahui untuk mengerjakan soal yang diberikan oleh guru menjadi kesulitan terbesar yang dihadapi oleh para siswa. Menurut Azizah pada penelitiannya tahun 2015, kesulitan memahami konsep menempati urutan pertama sedangkan urutan kedua adalah kesulitan memahami rumus. Kesulitan memahami konsep dan rumus ini sering membuat mata pelajaran fisika bukanlah mata pelajaran yang disenangi oleh siswa.

Salah satu upaya untuk mengurangi kesulitan belajar khususnya untuk bidang IPA adalah dengan menggunakan praktikum di Laboratorium. Menurut Susilo dan Gufron tahun 2018 dalam program kemitraan masyarakat, kemampuan dan pengetahuan peserta akan meningkat karena pada saat melakukan praktik langsung di Laboratorium merasa senang dan antusias.

Pengukuran adalah materi awal dari mata pelajaran IPA SMP khususnya bidang fisika, karena pada materi ini siswa SMP diperkenalkan untuk dapat melihat nilai dari besaran fisika suatu benda yang dapat terukur. Untuk dapat melakukan pengukuran dibutuhkan suatau alat yang namanya alat ukur yang sudah terstandarkan, dimana pada alat ukur tersebut terdapat skala dari satuan internasional. Ketelitian alat ukur juga sangat mempengaruhi perolehan hasil ukuran, semakin teliti sebuah alat ukur maka hasil ukuran yang diperoleh juga akan semakin memdekati ukuran yang sebenarnya (Tipler, 2001).

Secara umum pada materi pembelajaran mengenai alat ukur siswa SMP diajarkan untuk menggunakan jangka sorong, micrometer skrup, neraca empat lengan, amperemeter dan voltmeter, yang mana pada setiap alat ukur memiliki prosedur pembacaan yang berbeda-beda. Pembacaan hasil pengukuran pada neraca empat lengan hasil pengukuran dengan menjumlahkan angka-angka yang ditunjuk pada masingmasing lengan, pada jangka sorong dan micrometer skrup perlu memperhatikan angka yang ditunjuk oleh skala utama dan nonius sedangkan pada amperemeter dan voltmeter perlu memperhatikan angka maksimum skala yang ditunjuk jarum dan skala batas maksimum arus maupun tegangan listrik.

Pembacaan pada alat ukur khususnya jangka sorong dan multimeter skrup cukup sulit untuk diperagakan atau dibaca oleh guru maupun siswa, hal ini karena skala pada kedua alat tersebut cukup kecil untuk dilihat (Murdoko dkk, 2017). Seiring perkembangan teknologi kesulitan pembacaan tersebut dapat dihilangkan dengan menggunakan alat digital. Penggunaan alat ukur digital lebih praktis, tetapi mengurangi keterampilan dalam pengukuran karena hasil pengukuran langsung tertera pada display, sehingga sering tidak perlu diajarkan di dalam kelas, selain itu materi yang diujikan dalam Ujian Nasional untuk SMP adalah alat ukur non digital.

Keberadaan alat ukur di dalam laboratorium khususnya laboratorium IPA sangat penting, karena dapat memperkenalkan dan membiasakan alat ukur kepada siswa, namun beberapa sekolah yang berada di daerah belum memiliki fasilitas tersebu. Berdasar hasil survey yang dilakukan oleh Tim Program Studi Pendidikan Fisika UKI pada Januari 2018, menemukan SMP Pusaka yang berada di Rawaselang belum memiliki alat ukur. Usaha dari Tim Pendidikan Fisika UKI adalah menyumbangkan alat ukur berupa jangka sorong, mikrometer sekrup dan multitester, serta memberikan pelatihan kepada siswa penggunaan alat ukur tersebut.

\section{SOLUSI/TEKNOLOGI}

Pengabdian kepada masyarakat ini dilaksanakan pada 9 Maret 2018 di SMP Pusaka, kecamatan Ciranjang kelas 7 sejumlah 29 siswa. Pengabdian dilakukan dengan memberikan pelatihan menggunakan alat-alat ukur yang sering digunakan di laboratorium fisika dimana pembacaan alat ukur tersebut sering ditanyakan dalam soal Ujian Nasional. Pelatih menggunakan modul yang diberikan kepada setiap siswa, 
modul tersebut berisi cara pembacaan skala pada jangka sorong, mikrometer skrup dan multitester. Pelatih juga memberikan Lembar Kerja Siswa (LKS), dengan perintah siswa mengukur benda-benda yang disediakan dan menuliskan hasil ukurannya ke dalam LKS.

Dalam pelaksanaan pelatihan, pelatih dibantu oleh beberapa asisten yang mendampingi siswa pada saat melakukan pengukuran. Setelah pelatihan selesai, pelatih memberikan kuesioner kepada siswa untuk mengetahui respon dari siswa mengenai pelatihan yang diberikan. Untuk mengetahui persentase respon siswa digunakan persamaan :

$$
X=\frac{r}{N} \times 100 \%
$$

Dengan $X$ adalah persentase respon, $r$ total skor yang diperoleh dan $N$ adalah skor maksimum. Kategori respon ditunjukkan pada tabel 1.

Tabel 1. Kategori respon siswa

\begin{tabular}{lll}
\hline No & Persentase & Kategori Respon \\
\hline 1 & $80,1 \%-100 \%$ & Baik \\
2 & $60,1 \%-80,0 \%$ & Cukup Baik \\
3 & $40,1 \%-60,0 \%$ & Netral \\
4 & $20,1 \%-40,0 \%$ & Kurang Baik \\
5 & $00,0 \%-20,0 \%$ & Tidak Baik \\
\hline
\end{tabular}

\section{HASIL DAN DISKUSI}

Pada pelatihan ini tim pelatih dari Program Studi Pendidikan Fisika UKI memberikan materi tentang cara pembacaan pada alat ukur jangka sorong, mikrometer sekrup dan multitester. Pada saat pelatihan tim pelatih memberikan cetakkan modul pelatihan pada masing-masing siswa. Pelatihan ini dihadiri oleh siswa dan guru SMP Pusaka Rawaselang, peran guru dalam pelatihan ini sebagai pendamping siswa.

Pada tahap awal pelatihan ini pelatih memberikan materi pelatihan yang dipresentasikan dengan menggunakan media LCD Proyektor, untuk menjelaskan cara membaca hasil pengukuran dari ketiga alat ukur tersebut, seperti yang ditunjukkan pada gambar 1. Berdasar tabel 2, menurut para siswa materi yang diberikan dalam modul jelas dan mudah dibaca dengan persentase $88,3 \%$ yaitu dengan kriteria baik. Menambah tingkat keterampilan dan pengetahuan dengan persentase respon sebesar 91,0 \%, materi berurut dari termudah ke tersulit dengan respon 82,1\%, mudah dipahami dan dipraktekan dengan persentase respon sebesar 87,6\%, serta sesuai dengan harapan siswa dengan persentase respon sebesar $84,1 \%$. Hal ini menunjukkan bahwa modul yang diberikan kepada siswa pemilihan tulisan, ukuran gambar dan bahasa yang digunakan dalamnya sesuai dengan karakter dari siswa. Secara umum respon siswa terhadap materi pelatihan sebesar 86,6 \% dengan kriteria baik, ini menunjukkan respon positif dari siswa terhadap materi yang disampaikan oleh tim pelatih dari Program Studi Pendidikan Fisika UKI.

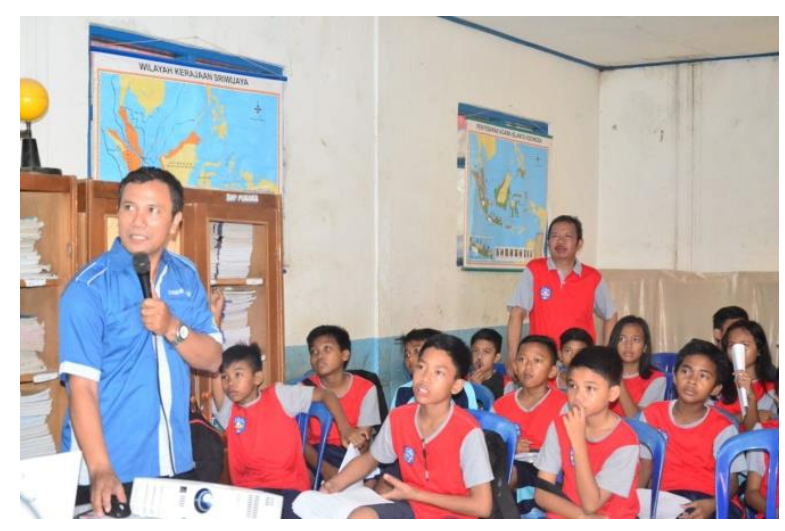

Gambar 1. Penyampaian materi pelatihan kepada siswa SMP Pusaka Rawaselang 




Gambar 2. Pendampingan kepada siswa mempraktikan pengukuran dengan alat ukur

Tabel 2. Respon siswa terhadap materi pelatihan

\begin{tabular}{clcc}
\hline No & \multicolumn{1}{c}{ Pernyataan } & Nilai (\%) & Kategori \\
\hline 1 & Tulisan dalam materi pelatihan jelas dan mudah dibaca & 88,3 & Baik \\
2 & $\begin{array}{l}\text { Kualitas materi pelatihan dapat menambah tingkat } \\
\text { keterampilan dan pengetahuan }\end{array}$ & 91,0 & Baik \\
3 & $\begin{array}{l}\text { Tahapan materi pelatihan sedah berurutan dari materi } \\
\text { yang paling mudah dengan materi paling sukar }\end{array}$ & 82,1 & Baik \\
4 & $\begin{array}{l}\text { Materi pelatihan mudah dipahami dan mudah diterapkan } \\
\text { dalam praktek }\end{array}$ & 87,6 & Baik \\
5 & Materi pelatihan sesuai dengan harapan anda & 84,1 & Baik \\
\hline & Rata-rata & $\mathbf{8 6 , 6}$ & Baik \\
\hline
\end{tabular}

Setelah penyampaian materi, siswa dibagi dalam beberapa kelompok untuk mempraktikan menggunakan alat ukur tersebut. Untuk penggunaan jangka sorong dan mikrometer sekrup digunakan uang logam untuk diukur diameter dan ketebalannya, sedangkan untuk penggunaan multitester digunakan baterai dan lampu untuk mengukur arus listrik dan tegangan listrik. Hasil pengukuran dari siswa dituliskan dalam lembar kerja siswa yang telah disediakan. Selama praktik menggunakan alat ukur para siswa didampingi oleh tim pelatih untuk membantu siswa ketika mengalami kesulitan dalam melakukan pengukuran, seperti ditunjukkan pada gambar 2 .

Berdasarkan tabel 3 diperoleh bahwa menurut siswa pelatih menguasi materi dengan baik, dengan persentase respon 85,5 $\%$. Selama memberikan pemaparan pelatih dirasa cukup mampu memberikan gambaran pelatihan secara umum, dengan persentase $80,0 \%$. Pelatih menggunakan bahasa yang dimengerti oleh siswa sehingga peserta dapat mengerti dengan jelas materi yang disampaikan siswa, dengan persentase respon sebesar 89,7 \%. Pelayanan yang diberikan pelatih juga mendapatkan respon yang baik oleh peserta, pelayanan pendampingan terhadap siswa memperoleh persentase respon sebesar $88,3 \%$, pelayanan terhadap pertanyaan siswa memperoleh 84,1 $\%$, pelayanan terhadap keluhan atau kesulitan siswa memperoleh 81,4\%. Dalam melaksanakan pelayanannya dalam pelatih, tim pelatih juga memperoleh kesan tidak membeda-bedakan atau bersifat adil kepada seluruh siswa peserta pelatihan. Dengan respon sebesar 91,0 \%. Secara umum respon siswa terhadap pelatih menunjukkan respon yang positip, dengan rata-rata sebesar 85,7 $\%$ pada kriteria baik. Hal ini berarti bahwa dalam melaksanakan pelatihan, tim dari Program Studi Pendidikan Fisika memberikan pelayanan yang baik dan mengerti kebutuhan siswa, dalam penyampaiannya menggunakan bahasa yang mudah dipahami oleh siswa, serta selama pelatihan siswa merasa senang dan tidak terbebani. 
Tabel 3. Respon siswa terhadap pelatih

\begin{tabular}{|c|l|c|c|}
\hline No & \multicolumn{1}{|c|}{ Pernyataan } & Nilai (\%) & Kategori \\
\hline 1 & Pelatih menguasai pelatihan & 85,5 & Baik \\
\hline 2 & $\begin{array}{l}\text { Pelatih menjelaskan tujuan pelatihan dan gambaran } \\
\text { pelatihan secara umum dari awal pelatihan }\end{array}$ & 80,0 & $\begin{array}{c}\text { Cukup } \\
\text { Baik }\end{array}$ \\
\hline 3 & $\begin{array}{l}\text { Pelatih menyajikan pelatihan dengan jelas dan bahasanya } \\
\text { mudah dimengerti }\end{array}$ & 89,7 & Baik \\
\hline 4 & Pelatih selalu mendampingi peserta selama proses pelatihan & 88,3 & Baik \\
\hline 5 & $\begin{array}{l}\text { Pelatih memberikan kesempatan pada peserta untuk } \\
\text { bertanya atau menyampaikan pendapat }\end{array}$ & 84,1 & Baik \\
\hline 6 & $\begin{array}{l}\text { Pelatih mendengarkan dan memperhatikan keluhan, usul } \\
\text { dan saran dari peserta pelatihan }\end{array}$ & 81,4 & Baik \\
\hline 7 & $\begin{array}{l}\text { Pelatih memperlakukan peserta pelatihan secara adil, tidak } \\
\text { memihak atau membeda-bedakan }\end{array}$ & 91,0 & Baik \\
\hline & $\quad$ Rata-rata & $\mathbf{8 5 , 7}$ & Baik \\
\hline
\end{tabular}

Pengabdian kepada masyarakat yang dilakukan oleh Program Studi Pendidikan Fisika, FKIP, UKI ini dilaksanakan sebagai salah satu pengamalan Tridharma Perguruan Tinggi, selain itu untuk menjawab kebutuhan SMP Pusaka akan kebutuhan alat ukur untuk mendukung mendukung pembelajaran IPA, khususnya mata pelajaran Fisika. Dengan adanya respon positip dari para siswa, mengindikasikan bahwa kegiatan pelatihan ini memberikan manfaat bagi siswa, dan bagi sekolah secara umum.

\section{KESIMPULAN}

Pelatihan penggunaan alat ukur kepada siswa SMP Pusaka Rawaselang disambut positif oleh para siswa, hal ini terbukti dari respon dari siswa menyatakan bahwa materi pelatihan menambah pengetahuan, mudah dipahami dan dipalikasikan dengan persentase sebesar 86,6 \% dengan kriteria baik. Respon para siswa terhadap pelatih dari Tim Program Studi Pendidikan Fisika UKI adalah pelatih memberikan perhatian, pendampingan dan menyajikan materi dengan baik dengan persentase sebesar $85,7 \%$.

\section{UCAPAN TERIMA KASIH}

Pada kesempatan ini tim penulis mengucapkan terimakasih untuk pimpinan
Universitas Kristen Indonesia, selaku instansi yang mengutus kami melaksanakan pengabdian kepada masyarakat. Kami juga berterimakasih kepada pimpinan Yayasan Pusaka serta pimpinan SMP Pusaka Rawaselang yang menyediakan kami tempat untuk melakukan pengabdian dalam bentuk pelatihan ini.

\section{PUSTAKA}

Azizah, Rismatul., Lia Yuliati dan Eny Latifah. 2015. Kesulitan Pemecahan Masalah Fisika pada Siswa SMA. Jurnal Penelitian Fisika dan Aplikasinya (JPFA) Vol. 5 No. 2 pp $44-50$.

Susilo dan Gurfon Amirullah. 2018. Pengelolaan dan Pemanfaatan Laboratorium Sekolah bagi Guru Muhammadiyah di Jakarta Timur. Jurnal SOLMA Vol. 7 No. 1 pp 127 $-137$.

Tipler, Paul A. 2001. Fisika untuk Sains dan Teknik. Erlangga : Jakarta

Murdoko, Eddy., Isa Akhlis dan Suharto Linuwih. 2017. Pengembangan Media Ajar Alat Ukur Panjang Mikrometer Sekrup dan Jangka Sorong untuk Siswa SMA dengan Perangkat Lunak Construct 2. Unnes Physics Education Journal (UPEJ) Vol. 6 No. 2 pp $73-79$. 